Article

\title{
Simulating the Feasibility of Dual Use Switchgrass on Cow-Calf Operations
}

\author{
Michael P. Popp ${ }^{1, *(D)}$, Amanda J. Ashworth ${ }^{2}\left(\mathbb{D}\right.$ and Charles P. West ${ }^{3}(\mathbb{D}$ \\ 1 Department of Agricultural Economics and Agribusiness, University of Arkansas, \\ Fayetteville, AR 72701, USA \\ 2 Poultry Production and Product Safety Research Unit, USDA-ARS, Fayetteville, AR 72701, USA; \\ amanda.ashworth@usda.gov \\ 3 Department of Plant and Soil Sciences, Texas Tech University, Lubbock, TX 79409, USA; chuck.west@ttu.edu \\ * Correspondence: mpopp@uark.edu; Tel.: +1-479-575-6838
}

check for updates

Citation: Popp, M.P.; Ashworth, A.J.; West, C.P. Simulating the Feasibility of Dual Use Switchgrass on Cow-Calf Operations. Energies 2021, 14, 2422. https://doi.org/10.3390/en14092422

Academic Editors:

Kimberly L. Jensen, Burton C. English and T. Edward Yu

Received: 30 March 2021

Accepted: 20 April 2021

Published: 23 April 2021

Publisher's Note: MDPI stays neutral with regard to jurisdictional claims in published maps and institutional affiliations.

Copyright: (c) 2021 by the authors. Licensee MDPI, Basel, Switzerland. This article is an open access article distributed under the terms and conditions of the Creative Commons Attribution (CC BY) license (https:// creativecommons.org/licenses/by/ $4.0 /)$.

\begin{abstract}
Meeting biorefineries' demands for lignocellulosic biomass will require sourcing feedstock without affecting the food or animal-feed supply. A decision-aid model can assess the dual use of switchgrass (Panicum virgatum L.) to maintain animal production while providing biomass. We simulated a mixed-farm operation with 156 ha of hay+pasture, 96 beef cows (Bos spp.), and poultry (Gallus gallus L.) production wherein the hay land was converted to switchgrass for dual use as biomass and forage. The cow-calf simulator tracked changes in forage and cattle production, economic returns, and net greenhouse gas (GHG) emissions. Dual use of switchgrass consisted of harvesting the first cutting (mid-June) for hay and the second cutting (October-November) for biomass. Dual use required a modest increase in fertilizer application and supplementing cows with corn grain to meet nutritional requirements. Converting hay land to dual-use switchgrass produced $122 \mathrm{Mg}$ of switchgrass, reduced net GHG emissions for autumn- and spring-calving operations by 3.4 and $3.6 \%$, respectively, and increased the farm profit by approximately $\$ 1500$ when priced at $\$ 50 \mathrm{Mg}^{-1}$ regardless of the calving season. This simulation provided evidence that conversion of hay lands (in a beef cow-calf and poultry farm) to dual-use switchgrass can avoid displacing food production, while supplying bioenergy feedstock and reducing climate-forcing gases.
\end{abstract}

Keywords: switchgrass; net greenhouse gas emissions; hay quality; cow-calf production

\section{Introduction}

Considerable interest exists to expand the supply of biofuels generated from lignocellulosic feedstock to avoid direct competition with food production as is currently the case with ethanol generated from corn (Zea mays L.) [1,2]. The intent is to source feedstock such that supplies of food, feed, and fiber are not diminished by the biomass harvest. Nearly 450,000 operations identified themselves as primarily crop, beef cattle, poultry or hay producers in the Southeastern U.S. (AL, AR, FL, GA, KY, LA, MS, NC, OK, SC, TN, TX, VA), managing approx. $55 \mathrm{MM}$ ha for beef cattle ranching and 14.5 MM ha for hay crops [3]. A subset of nearly 200,000 operations operated on $30 \mathrm{MM}$ ha as mixed operations of ranching, haying, and poultry production in 2017 [3]. Our study targets this type of farm as they would have access to the necessary equipment and poultry litter-a relatively cheap source of fertilizer nutrients - to accomplish a change in the forage species mix on their hay land. Estimating economic and sustainability impacts of introducing switchgrass (Panicum virgatum L.; SG) for making hay and supplying SG biomass to biorefineries while holding the cattle output constant is thus the focus of this analysis. Previous work, assessing the extent to which SG could be used profitably for grazing has found that, at a sufficiently high price for biomass, grazing-only and mechanical harvest for biomass after grazing could improve profitability [4,5]. Furthermore, cattle performed well on SG, and SG was economically optimal in comparison with other native warm-season grasses. 
Richner et al. [6] and McIntosh et al. [7] tested several native warm-season species for dual-purpose harvest (as hay early in the season and as biomass for biofuel late in the season), and revealed superior yield potential of SG. Popp et al. [8] investigated the potential to harvest switchgrass for hay in the mid-South state of Arkansas in early June and July (no late-season harvest) to (i) determine yield and hay-quality responses to N, P, and K fertilizers, and (ii) identify profit-maximizing rates of commercial fertilizer and/or poultry litter to manage soil fertility. While $\mathrm{P}$ and $\mathrm{K}$ fertilizer added little to the yield potential, SG yield did respond to $\mathrm{N}$ fertilizer. The use of poultry litter, in combination with inorganic fertilizer, was the profit-maximizing choice. Fertilizer rate recommendations vary with SG price and cost of nutrients. The on-line spreadsheet decision aid provides easy access to these rate recommendations along with feed quality and nutrient removal information [8].

Investigating the impacts of SG dual usage not only on farm-level agronomic productivity but also from a perspective of changes in dietary needs of the cattle herd offers insight about profitability changes and attendant feasibility for producers to adopt SG in lieu of conventional forages. In addition, tracking changes in net greenhouse gas (GHG) emissions answers questions related to sustainability. Hence, we aimed to quantify the effects of changing hay land from a conventional forage species mix of $45 \%$ by area of tall fescue (Lolium arundinaceum (Schreb.) S.J. Darbysh.; TF), 50\% bermudagrass (Cynodon dactylon (L.) Pers.; BG) and 5\% clovers (Trifolium spp.; C) to 100\% SG. The Forage and Cattle Analysis and Planning (FORCAP) model [9] was designed to model changes to cow-calf operating conditions and simulate their effects on farm-scale economic output and net GHG emissions. The model has been used in detailed analyses of weather effects and herd-size management [10], timing of calving season, weaning age, forage species selection, and fertilizer use [11]. The model simulates forage production, whether grazed or harvested as hay for eventual feed use or for sale. At the same time, the model tracks the grazing and supplemental feed intake on a user-specified parcel of land dedicated to pasture or hay. As such, stocking rate, calving season, weaning age, cattle breed, breeding failures and fertilizer use impact the annual cow-calf profitability when forage species grown on the farm are modified since the monthly forage growth and use (grazed/harvest or stockpiled) is simulated. The model can also track changes in herd size by way of replacement heifer retention but the intent is to model outcomes of a herd that has reached steady state where a sufficient number of replacement heifers are retained to maintain the herd while accounting for feed needs of growing calves and replacement heifers, first-calving cows, mature cows and herd sires on a monthly time step as the calving season modifies the monthly nutritional needs of the herd. Since performing this type of field research is expensive and time-consuming, this tool is helpful to simulate agronomic, economic, and net GHG emissions effects of changes in the forage species mix on a beef cow-calf operation to assist with planning efforts prior to implementation.

The objective was to compare operations with different hay management. The status quo is to use conventional forage species with two cuttings in May and August. The alternative employs SG harvested for hay in June followed by a biomass harvest in late October or early November. Since this change adds forage demand, holding the amount of land used constant, we adjust the fertilizer application rate and add supplemental corn to maintain the cattle output. In addition, higher establishment and harvest costs of SG in comparison to conventional forage species are accounted for to calculate a breakeven price for the second cut of SG in autumn and thereby assess the supply potential for the region from this type of farm. To assess sustainability, we quantify changes in net GHG emissions. To offer insight to producers with different calving seasons, we enumerate differences between spring- and autumn calving.

\section{Materials and Methods}

\subsection{Baseline}

Similar to the approach employed by Tester et al. [10], we used a baseline herd size of 96 cows calving annually using 125 ha for pasture and 31 ha for hay as that farm size 
represents the average for mixed beef cattle, hay, and poultry operations in the Southeastern U.S. The land dedicated to pasture was rotationally grazed and consists of conventional forage species typical of the U.S. mid-South (25\% BG, $65 \%$ TF and $10 \%$ C by area). Winter wheat (Triticum aestivum L.) is sod seeded on the BG portion of pastures to increase forage availability and nutritive value in the spring. The baseline operation uses $38 \mathrm{~kg} \mathrm{~N} \mathrm{ha}^{-1}$ sourced from ammonium nitrate (34-0-0) applied after the first cut and $4.5 \mathrm{Mg} \mathrm{ha}^{-1}$ of poultry litter (3-3-3) on land dedicated for hay; where the pastures receive $1.1 \mathrm{Mg} \mathrm{ha}^{-1}$ of poultry litter. Winter wheat receives $57 \mathrm{~kg} \mathrm{ha}^{-1}$ of $\mathrm{N}$ as ammonium nitrate in the spring. The baseline model farm represents an intensively managed operation with equipment for establishing and maintaining forages fertilized with poultry litter to provide sufficient amount and quality of forage to meet the herd's nutrition needs and excess sale of hay in an average weather year. To maintain the body condition of the breeding herd, FORCAP supplements winter feed rations with corn to meet crude protein $(\mathrm{CP})$ and total digestible nutrient (TDN) requirements with a standard assumption of selling weaned calves at 7 months of age. As such, the baseline operation with a herd calving in autumn produces 139 round bales of hay weighing $479 \mathrm{~kg}$ dry matter or $544 \mathrm{~kg}$ as-is at $12 \%$ wet basis moisture content $\left(\mathrm{M}_{\mathrm{W}}\right)$ from excess pasture forage production, and 309 round bales of hay from hay land [9]. Hay is harvested from pastures when forage growth exceeds grazing demand. Hay land is harvested twice per year by mowing, raking, baling, and transporting round bales to storage areas for eventual feeding or sale.

We used FORCAP to model the biophysical responses to changing (i) calving season; and, (ii) quantity and quality of forages produced. We also tracked net GHG emissions using a partial life cycle assessment (LCA), and economic performance.

\subsection{Partial Lifecycle Assessment}

The FORCAP model tracks fuel, fertilizer, and twine use for estimating net GHG emissions converted to $\mathrm{kg}$ of carbon dioxide equivalent $\left(\mathrm{CO}_{2}\right.$ eq.) for the farm as a whole, on a per unit of land basis, and on a per unit of animal-live weight sold basis (Table 1).

Table 1. Carbon dioxide equivalent emission factors and costs of inputs.

\begin{tabular}{lccc}
\hline \multicolumn{1}{c}{ Input } & Unit & $\mathbf{C O}_{\mathbf{2}}$ eq. $\mathbf{~ k g} /$ Unit & USD/Unit ${ }^{\mathbf{5}}$ \\
\hline Fuel & & & \\
$\quad$ Diesel & $\mathrm{L}$ & $3.274^{1}$ & 0.67 \\
$\quad$ Gasoline & $\mathrm{L}$ & 2.853 & 0.70 \\
Fertilizer & $\mathrm{kg}$ & $0.942^{2}$ & 0.025 \\
$\quad$ Poultry manure [3-3-3] & $\mathrm{kg}$ & $5.023^{3}$ & 0.397 \\
$\quad$ Ammonium nitrate [34-0-0] & $\mathrm{kg}$ & 0.572 & 0.040 \\
$\quad$ Lime & & & \\
Other & $479 \mathrm{~kg}$ bale & $3.381^{1}$ & 1.00 \\
$\quad$ Twine & $\mathrm{kg}$ & $0.320^{4}$ & 0.20 \\
$\quad$ Supplemental corn fed &
\end{tabular}

Notes: ${ }^{1}$ Previously reported carbon dioxide equivalent $\left(\mathrm{CO}_{2}\right.$ eq. $)$ emission factors were applied to different inputs as shown above. Multiple GHGs comprising mainly carbon dioxide, nitrous oxide, and methane, are associated with their global warming potential [12] and converted to their $\mathrm{CO}_{2}$ eq. carbon footprint [13,14]. The value for gasoline and twine, using agricultural plastics, is from Lal [15]. ${ }^{2}$ Composting of poultry litter is assessed a $0.777 \mathrm{~kg}$ of $\mathrm{CO}_{2}$ eq. per kg of dry poultry litter [13]. ${ }^{3} \mathrm{GHG}$ emissions during manufacture vary by nitrogen fertilizer type [13]. Nitrous oxide emissions of $5.518 \mathrm{~kg}$ of $\mathrm{CO}_{2} \mathrm{eq}$. per $\mathrm{kg}$ of nitrogen applied are in the form of direct (nitrification and denitrification) and indirect (volatilization, leaching, and runoff) agricultural $\mathrm{N}_{2} \mathrm{O}$ emissions [12]. These emissions vary with the $\mathrm{N}$ content in fertilizer and poultry litter. Transport to the farm adds a constant footprint of $0.106 \mathrm{~kg}$ of $\mathrm{CO}_{2} \mathrm{eq} . / \mathrm{kg}$ of material moved from regional warehouses to farms except for poultry manure [16]. ${ }^{4}$ Taken from Rotz et al. [17]. ${ }^{5}$ Cost information for fuels and fertilizer were sourced from archived cost of production information provided by Mississippi State University [18]. The cost for corn is the Arkansas annual average price with $\$ 0.02 \mathrm{~kg}^{-1}$ added for bulk delivery (USDA [19]).

The boundary of the LCA includes the fuel use for delivery of cattle to livestock auctions and assesses $\mathrm{CO}_{2}$ eq. emissions for purchased inputs and poultry litter. The model also tracks cattle emissions of methane $\left(\mathrm{CH}_{4}\right)$, carbon dioxide $\left(\mathrm{CO}_{2}\right)$, and nitrous 
oxide $\left(\mathrm{N}_{2} \mathrm{O}\right)$ emissions from respiration, enteric fermentation as well as feces and urine depositions linked to $\mathrm{CP}$ and TDN intake $[11,12,20]$ that are converted to their $\mathrm{CO}_{2}$ eq. footprint given their global warming potential using IPCC guidelines [12]. Details related to GHG emissions tracking are in the reference manual for FORCAP [9]. Finally, FORCAP tracks soil carbon sequestration from forage production by tracking $C$ concentrations in above- and below-ground forage production as detailed in Popp et al. [21].

\subsection{Production Practices}

Table 2 summarizes cattle and forage production management settings used in FORCAP [9]. A moderately low stocking rate is used on pasture given the modest level of fertilizer input summarized in Table 3.

Table 2. Select herd and hay management characteristics for a beef cow-calf operation with 96 cows calving in autumn and spring.

\begin{tabular}{|c|c|c|c|}
\hline Description & Quantity & Herd Size Description & Quantity \\
\hline Days on hay \& supplements 1 & $128(122)^{2}$ & Cows (avg. age $65 \mathrm{~m}$ ) & 80 \\
\hline Days on pasture ${ }^{1}$ & $237(243)$ & Young cows (avg. age $30 \mathrm{~m}$ ) & 16 \\
\hline Breeding failures ${ }^{3}$ & $6 \%(20 \%)$ & Cow herd size 6 & 96 \\
\hline Annual cow death losses & $1 \%$ & Replacement heifers & 17 \\
\hline Annual calf death losses & $3 \%$ & Herd sires or bulls needed ${ }^{7}$ & 4 \\
\hline Avg. culling age of cows & 7.58 & Male calves sold & $44(37)$ \\
\hline Avg. number of calves over life of cow 4 & 6 & Female calves sold & $27(20)$ \\
\hline Weight of mature cow in kg & 567 & Cull cows & 16 \\
\hline Weight of first-calving cow in $\mathrm{kg}$ & 454 & Stocking rate (hd ha ${ }^{-1}$ ) & 0.77 \\
\hline Weaning age in months ${ }^{5}$ & 7 & Forage $\left(544 \mathrm{~kg} \text { bales } @ 12 \% \mathrm{M}_{\mathrm{W}}\right)^{8}$ & Quantity \\
\hline Age of replacements at first breeding & 15 & Harvest efficiency & $60 \%$ \\
\hline Avg. birth weight in $\mathrm{kg}$ & 41 & Hay produced & $448(411)$ \\
\hline Avg. steer weaning weight in $\mathrm{kg}$ & 252 & Hay sold & $44(43)$ \\
\hline Avg. heifer weaning weight in $\mathrm{kg}$ & 236 & Hay waste (feed \& store) & $15 \%$ \\
\hline Avg. bull weight in $\mathrm{kg}$ & 907 & Biomass for biorefineries & 254 \\
\hline
\end{tabular}

${ }^{1}$ Since nutritional needs of the herd vary by lactation and gestation stage of the cow herd by month and attendant monthly differences in calf and replacement heifer weights, the forage consumption varies by month and affects the hay harvest from pastures and attendant forage quality driving supplemental feed use. ${ }^{2}$ Numbers in parentheses indicate changes with spring calving compared to calving in autumn. ${ }^{3}$ Breeding failure rates vary between autumn (50\% September, 50\% October) and spring (50\% February, 50\% March) due to fescue toxicosis effects $[22,23] .{ }^{4}$ The number of calves a cow produces and breeding failures drives the number of replacement heifers needed to maintain herd size. ${ }^{5}$ Weaning age of calves determines sale months that vary by calving season and thereby seasonal sale prices. ${ }^{6}$ Given land resources for pasture and hay, the cow herd makeup, 80 mature and 16 first-calving young cows, drives nutritional needs of the herd. The herd size was chosen such that hay production would allow for minimal sale of excess round bales. ${ }^{7}$ The number of herd sires required is based on a maximum of 25 cows per bull and a four-year useful life. ${ }^{8}$ All forage produced on pasture and hay is tracked in terms of dry matter production above ground as most literature on yield response deals with dry matter production. Since not all forage production is grazed (trampling, etc.) or harvested as hay (cutting height, baling losses, etc.), harvest efficiency adjusts forage production to forage grazed and captured as hay with further storage and feeding losses anticipated for hay fed. Switchgrass (SG) harvested for biomass is tracked separately in model runs where SG was substituted for conventional hay and is reported as biomass for biorefineries.

Switchgrass yield is relatively non-responsive to $\mathrm{P}$ and $\mathrm{K}[8,24]$ and hence annual applications of $\mathrm{P}$ and $\mathrm{K}$ from poultry litter are considered sufficient for a dry matter yield of $14.4 \mathrm{Mg} \mathrm{ha}{ }^{-1}$. That yield target leads to the same amount of hay in the first cutting from SG as would be available from two cuttings from conventional BG + TF + C hay fields as estimated in FORCAP [9]. Supplemental N needs for that SG yield target were met using $42 \mathrm{~kg} \mathrm{~N} \mathrm{ha}^{-1}$ from ammonium nitrate and $134.5 \mathrm{~kg} \mathrm{~N} \mathrm{ha}^{-1}$ from poultry litter and estimated using Popp et al.'s [8] switchgrass yield response to $\mathrm{N}$ decision aid as a guideline. For two cuttings of switchgrass, we use a switchgrass yield of $5.6 \mathrm{Mg} \mathrm{ha}^{-1}$ without $\mathrm{N}$ fertilizer and a yield response of $50 \mathrm{~kg} \mathrm{ha}^{-1}$ per $\mathrm{kg} \mathrm{N} \mathrm{ha}^{-1}$ applied. Further, $55 \%$ of the annual yield is harvested in the first cut as hay at $7 \% \mathrm{CP}$ and $51 \% \mathrm{TDN}$. The second cutting in late autumn makes up the remaining $45 \%$ and is harvested preferably after senescence to minimize the nutrient concentration in the biomass [24]. Together with the hay harvested from pastures, which was 102 bales for spring calving herds (requiring 
more forage with calves at side in the summer) vs. 139 bales harvested on operations calving in autumn, FORCAP estimates of the quantity weighted average of hay quality are shown in Table 3 and a function of 20-yr hay quality estimates by month as collected in the Arkansas Feedstuffs database used in FORCAP [9].

Table 3. Summary of soil amendment and hay quality differences for conventional forage species mix vs. switchgrass on hay land.

\begin{tabular}{|c|c|c|}
\hline Description & $B G+T F+C^{1}$ & SG $^{1}$ \\
\hline \multicolumn{3}{|l|}{ Soil amendments } \\
\hline Lime & \multicolumn{2}{|l|}{ 2.2 $\mathrm{Mg} \mathrm{ha}^{-1}$ every $4 \mathrm{yr}$ (hay and pastures) } \\
\hline Poultry Litter (3-3-3) & \multicolumn{2}{|c|}{$1.1 \mathrm{Mg} \mathrm{ha}^{-1}$ dry matter every yr (pasture) $\& 4.5 \mathrm{Mg} \mathrm{ha}^{-1}$ every yr (hay) } \\
\hline Ammonium nitrate (34-0-0) & $\begin{array}{l}112 \mathrm{~kg} \mathrm{ha}^{-1} \text { on hay land only and } 168 \mathrm{~kg} \mathrm{ha}^{-1} \\
\text { for winter annuals on BG portion of pastures }\end{array}$ & $\begin{array}{l}123 \mathrm{~kg} \mathrm{ha}^{-1} \text { on hay land only and } 168 \mathrm{~kg} \mathrm{ha}^{-1} \\
\text { for winter annuals on BG portion of pastures }\end{array}$ \\
\hline \multicolumn{3}{|l|}{ Hay quality } \\
\hline Autumn calving & $58.4 \%$ TDN $14.7 \%$ CP & $51.8 \%$ TDN $9.3 \% \mathrm{CP}$ \\
\hline Spring calving & $58.3 \%$ TDN $14.7 \%$ CP & $51.1 \%$ TDN $8.8 \%$ CP \\
\hline
\end{tabular}

Table 4. 2011-2020 average monthly cattle prices by cattle type, weight, and month, AR.

\begin{tabular}{ccccccc}
\hline \multicolumn{2}{c}{ Animal Description } & Apr $^{\mathbf{1}}$ & May & Sep & Oct & Annual Average \\
\hline & & & & $\$ \mathrm{~kg}^{-1}$ & live weight & \\
Steers $^{2}$ & $227-272 \mathrm{~kg}$ & 387 & 376 & 351 & 365 & 371 \\
Heifers $^{2}$ & $227-272 \mathrm{~kg}$ & 343 & 338 & 313 & 321 & 330 \\
Cows $^{3}$ & $75-80 \% \mathrm{Lean}$ & 162 & 162 & 141 & 136 & 153 \\
Herd Sires $^{4}$ & $454-908 \mathrm{~kg}$ & 207 & 211 & 186 & 181 & 199 \\
\hline
\end{tabular}

${ }^{1}$ April and May sale months correspond with a two-month autumn calving period spanning September and October whereas September and October sale months correspond with a two-month spring calving period including February and March [25]. ${ }^{2}$ Medium and Large frame \#1 Muscle score animals. ${ }^{3}$ Breaking Utility and Commercial (75-80\% Lean) cows. ${ }^{4}$ Yield Grade $1-2$ cull herd sires.

Combined with 10-yr average prices for beef cattle sales (Table 4) and hay valued at $\$ 76.83 \mathrm{Mg}^{-1}$ or $\$ 41.83$ per $544 \mathrm{~kg}$ bale as-is [19], partial returns to cow-calf and hay production with changes in calving season and forage species mix employed for hay production could be calculated.

\subsection{Relative Profitability}

The FORCAP model calculates the cash operating profit $(\pi)$ of the operation as a result of proceeds from the sale of excess hay and biomass as well as cull animals and calves, less cash operating costs for purchased feed, fuel, feed additives, veterinary and drug charges, twine, marketing charges (sales commission, yardage, insurance and custom hauling), repair and maintenance, pasture maintenance and establishment, as well as operating interest to finance short-term cash operating expenses. Thus, $\pi$ assesses the operation's returns to land, management, and capital employed. Importantly, the tool does not track labor use nor are investment costs reported for land, breeding stock, buildings, and machinery as they are expected to be very similar for the operating scenario differences we explored. As such, this partial budgeting analysis captured changes across the calving season in cattle sales using the same size of breeding herd along with changes in forage production and attendant changes in supplemental feed corn use.

There are four scenarios that vary by (i) calving season-autumn or spring; and (ii) forage species mix on land dedicated to hay production-conventional BG + TF + C or SG. Relative changes in $\pi$ at a baseline SG price of $\$ 50 \mathrm{Mg}^{-1}$ dry matter available F.O.B. as 
staged at the farm, and other factors as enumerated above thus allow comparisons of the relative profitability and changes in the net GHG emissions footprint. Additionally, we solve for the break-even price of SG where $\pi$ is the same for autumn- or spring-calving cow herds by modifying the SG price. If the breakeven price is less than $\$ 50 \mathrm{Mg}^{-1}$, producers may consider adopting the practice of using SG as a hay source rather than from conventional forage species as it would be profitable to do so. Finally, a region-wide supply response to a SG market paying $\$ 50 \mathrm{Mg}^{-1}$ can be approximated if the operations modeled are similar in size, employ the same production practices, and experience the same biophysical responses as actual farm operations by multiplying the number of operations in the region with the estimated impact per farm.

\section{Results}

Tables 5 and 6 report the net GHG emission and profitability results, respectively. As highlighted in the middle and right-most columns, changes $(\Delta)$ in net GHG emissions (negative GHG emissions = soil carbon sequestration), a positive change (more carbon sequestration) is observed with higher-yielding SG in comparison to conventional hay production $(\mathrm{BG}+\mathrm{TF}+\mathrm{C})$, as expected. Indeed, FORCAP estimated aboveground forage dry matter biomass production of $14.4 \mathrm{Mg} \mathrm{ha}^{-1}$ for SG vs. $7.9 \mathrm{Mg} \mathrm{ha}^{-1}$ for the conventional forage species mix. Since soil organic carbon sequestration on pastures remained the same, the potential for additional storage was not as large as the yield differences. Nonetheless, it was a substantial component of the positive changes in the carbon footprint with the conversion to SG.

Table 5. Changes in net GHG emissions in $\mathrm{kg}$ of $\mathrm{CO} 2$ eq. per kg of live weight of cattle sold.

\begin{tabular}{|c|c|c|c|c|c|c|}
\hline \multirow{2}{*}{$\begin{array}{l}\text { Calving Season } \\
\text { Forage species }{ }^{1}\end{array}$} & \multicolumn{3}{|c|}{ Autumn } & \multicolumn{3}{|c|}{ Spring } \\
\hline & $\mathrm{BG}+\mathrm{TF}+\mathrm{C}$ & SG & $\Delta$ & $\mathrm{BG}+\mathrm{TF}+\mathrm{C}$ & SG & $\Delta$ \\
\hline & \multicolumn{2}{|c|}{$\mathrm{kg}$ of $\mathrm{CO}_{2}$ eq. $\mathrm{kg}^{-1}$ of cattle } & $\%$ & \multicolumn{2}{|c|}{$\mathrm{kg}$ of $\mathrm{CO}_{2}$ eq. $\mathrm{kg}^{-1}$ of cattle } & $\%$ \\
\hline Cattle $^{2}$ & 15.56 & 15.56 & & 17.05 & 17.05 & \\
\hline Forage $^{1}$ & -3.22 & -4.07 & 26.4 & -3.70 & -4.67 & 26.2 \\
\hline Agric. Inputs ${ }^{3}$ & 7.27 & 7.44 & -2.3 & 8.34 & 8.51 & -2.0 \\
\hline Total $^{4}$ & 19.61 & 18.94 & 3.4 & 21.68 & 20.89 & 3.6 \\
\hline
\end{tabular}

${ }^{1}$ Forages by way of photosynthesis are net sequestering based on above- and below-ground biomass production [13]. Species include 50\% bermudagrass (BG), 45\% tall fescue (TF), and 5\% clover (C) on land dedicated to hay production and $25 \% \mathrm{BG}, 65 \% \mathrm{TF}$, and $10 \% \mathrm{C}$ on pastures along with sod-seeded winter wheat on $25 \%$ of the pasture land. For the switchgrass (SG) option, 100\% switchgrass is employed on hay land with pasture forage species mix unchanged. ${ }^{2}$ Cattle emissions are from respiration, enteric fermentation, and nitrous oxide emissions. 3 Agricultural input use tracks changes in use of fertilizers (ammonium nitrate and poultry litter), fuel and gasoline, supplemental corn, and twine for baling. See Tables 3 and 6 for further detail. ${ }^{4}$ Farm-level net GHG emissions and estimates per unit area of land (156 ha) can be derived by using 26,391 and 22,978 kg of live weight of cattle sold annually for autumn- and spring-calving herds, respectively.

Fertilizer, fuel, corn, and twine-use increased with the change to SG from BG $+\mathrm{TF}+\mathrm{C}$, with negative net GHG emissions occurring owing to a heightened input-use driving greater GHG emissions. That negative impact is smaller for spring-calving operations as less forage was harvested and cattle needed less corn supplement given seasonal differences in nutrient requirements and available forage.

While the added agricultural input use is smaller with spring-calving herds, greater breeding failure rates are observed with greater incidence of fescue toxicosis [22] than in herds calving in autumn. This leads to lesser cattle output and greater net GHG emissions per $\mathrm{kg}$ of cattle produced as shown in the fourth row of Table 5. That output change by calving season, however, does not differ by the hay production method, as cattle graze the same pastures and changes in nutrient deficit as a result of moving to lower-quality SG (Table 3) are met with corn. Overall, the impact of shifting hay from conventional forage species to SG is positive in the context of net GHG emissions and similar in size in relative terms $(\Delta)$ across the calving season. 
Table 6. Estimated revenue and direct costs of a 96-cow herd by calving season and forage species mix at $\$ 50 \mathrm{Mg}^{-1}$ for biomass.

\begin{tabular}{|c|c|c|c|c|c|c|c|c|}
\hline \multirow{2}{*}{$\begin{array}{c}\text { Calving Season } \\
\text { Forage species mix }\end{array}$} & \multicolumn{4}{|c|}{ Autumn } & \multicolumn{4}{|c|}{ Spring } \\
\hline & \multicolumn{2}{|c|}{$\mathrm{BG}+\mathrm{TF}+\mathrm{C}^{3}$} & \multicolumn{2}{|c|}{$\mathrm{SG}^{3}$} & \multicolumn{2}{|c|}{$\mathrm{BG}+\mathrm{TF}+\mathrm{C}$} & \multicolumn{2}{|c|}{ SG } \\
\hline & \multicolumn{8}{|c|}{ GROSS RECEIPTS (\% of TOTAL RECEIPTS) } \\
\hline Cattle sales ${ }^{1}$ & $\$ 79,126$ & $(97.7)$ & $\$ 79,126$ & $(90.9)$ & $\$ 61,228$ & $(95.8)$ & $\$ 61,228$ & $(88.6)$ \\
\hline Excess hay (if any) ${ }^{2}$ & $\$ 1841$ & $(2.3)$ & $\$ 1841$ & $(2.1)$ & $\$ 1799$ & $(2.9)$ & $\$ 1799$ & $(2.6)$ \\
\hline Biomass (if any) ${ }^{2}$ & $\$ 0$ & $(0.0)$ & $\$ 6085$ & $(7.0)$ & $\$ 0$ & $(0.0)$ & $\$ 6085$ & $(8.8)$ \\
\hline \multirow[t]{2}{*}{ TOTAL RECEIPTS } & $\$ 80,966$ & $(100)$ & $\$ 87,051$ & $(100)$ & $\$ 63,026$ & $(100)$ & $\$ 69,111$ & $(100)$ \\
\hline & \multicolumn{8}{|c|}{ DIRECT COST (\% of TOTAL RECEIPTS) } \\
\hline Fertilizer costs ${ }^{3}$ & $\$ 15,877$ & $(19.6)$ & $\$ 16,015$ & $(18.4)$ & $\$ 15,877$ & $(25.2)$ & $\$ 16,015$ & $(23.2)$ \\
\hline $\begin{array}{l}\text { Forage maint. \& winter } \\
\text { annuals } 4\end{array}$ & $\$ 10,499$ & $(13.0)$ & $\$ 12,809$ & (14.7) & $\$ 10,499$ & $(16.7)$ & $\$ 12,809$ & (18.5) \\
\hline $\begin{array}{l}\text { Cattle \& equipment } \\
\text { related Charges }{ }^{5}\end{array}$ & $\$ 21,076$ & $(26.0)$ & $\$ 21,446$ & $(24.6)$ & $\$ 19,926$ & $(31.6)$ & $\$ 20,296$ & $(29.4)$ \\
\hline Twine & $\$ 449$ & $(0.6)$ & $\$ 703$ & $(0.8)$ & $\$ 412$ & $(0.7)$ & $\$ 666$ & $(1.0)$ \\
\hline Corn & $\$ 381$ & $(0.5)$ & $\$ 1976$ & $(2.3)$ & $\$ 265$ & $(0.4)$ & $\$ 1500$ & $(2.2)$ \\
\hline Total direct cost & $\$ 48,281$ & $(59.6)$ & $\$ 52,949$ & $(60.8)$ & $\$ 46,978$ & $(74.5)$ & $\$ 51,286$ & $(74.2)$ \\
\hline Operating interest ${ }^{6}$ & $\$ 1147$ & $(1.4)$ & $\$ 1258$ & $(1.4)$ & $\$ 1116$ & $(1.8)$ & $\$ 1218$ & $(1.8)$ \\
\hline Cash Operating Profit $(\pi)$ & $\$ 31,539$ & $(39.0)$ & $\$ 32,845$ & $(37.7)$ & $\$ 14,932$ & $(23.7)$ & $\$ 16,607$ & $(24.0)$ \\
\hline
\end{tabular}

${ }^{1}$ Cattle sales include cull animal and calf sales (Table 2). Live weight per head and by animal type remains constant but price changes (Table 4). ${ }^{2}$ Hay sales are valued at 10 -year average prices adjusted for quality to $\$ 76.83 \mathrm{Mg}^{-1}$ or $\$ 41.83$ per $544-\mathrm{kg}$ bale at $12 \%$ M.C. [19] and compares to SG biomass at $\$ 23.96$ per bale at $12 \%$ M.C. or $\$ 50 \mathrm{Mg}^{-1}$ dry matter. ${ }^{3}$ See Tables 1 and 3 for details. ${ }^{4}$ Maintaining and establishing forages is assigned a cost of $\$ 346 \mathrm{ha}^{-1}$ prorated over ten years and includes custom application of herbicide for burn down, planting/sprigging, and seed as detailed in Popp and Nalley [26]. Since SG is more costly in the sense that first year harvest is not recommended [27], we conservatively increase the weighted prorated annual cost per unit area of land for both pasture and hay land from $\$ 34.60 \mathrm{ha}^{-1}$ per year to $\$ 49.4 \mathrm{ha}^{-1} .{ }^{5}$ Cattle and equipment charges include costs related to purchase and sale of animals and include yardage, insurance, and custom transport charges as well as herd sire replacement costs, salt and mineral supplements, veterinary and drug charges, estimated annual equipment repair and maintenance, fuel, and a charge for a farm vehicle of $\$ 1$ per calving cow. They vary marginally on the basis of number of head sold. The interested reader is encouraged to examine further details at https:/ /agribusiness.uark.edu/decision-support-software.php (23 March 2021) for both FORCAP [9] and ENCAP [27]. ${ }^{6}$ Operating interest is charged on the total direct cost for 6 months at $5 \%$ per annum.

Cash operating profits $(\pi)$, detailed in Table 6 , are returns to land, labor, and capital. They are needed to cover equipment and building ownership charges, land rent or an opportunity cost of capital employed for land, as well as capital cost required for acquisition of the breeding stock. These numbers do not reflect profitability of a cow calf-operation but rather are used to assess relative profitability across calving season and forage species selection. Across the four scenarios, gross receipts are higher with calving in autumn given greater cattle output (fewer breeding failures) at seasonally higher sale prices (Table 4) in comparison to spring-calving herds. Having modified the fertilizer use to have the same level of hay production with or without the use of SG leads to no change in excess hay sales. However, the addition of SG sales to biorefineries, even at a low price of $\$ 50 \mathrm{Mg}^{-1}$, offers the same revenue potential regardless of the calving season.

Since only a $10 \%$ increase in ammonium nitrate was required to have the same level of excess hay sales with SG compared with the conventional forage species (Table 3), the fertilizer cost difference was quite small. Fuel use for cutting, haying and baling was increased with greater SG yield as were repair and maintenance charges on the baler. Cattle and equipment-related charges were higher for operations calving in autumn mainly because of marketing and transport cost differences with greater cattle output compared to spring-calving operations. Twine use increased when SG was introduced as an additional 254 bales of SG were wrapped regardless of the calving season. Feeding of corn had a larger impact for operations calving in autumn, since lactating cows required greater nutritive assistance during the winter months than spring-calving cows that would be grazing high quality forage during the peak lactation months. The heightened cost with SG 
under either calving season, however, was much smaller than the additional SG revenue potential created.

Profitability increased regardless of the calving season since added SG sales receipts more than offset the added cost of fertilizer, twine, and corn. In fact, for operations calving in autumn, the SG price could drop from $\$ 50$ to $\$ 39.27 \mathrm{Mg}^{-1}$ for an operation's profitability to remain the same compared to using conventional hay forage species. That same breakeven price for spring-calving operations, which were less profitable because of lesser cattle output than operations calving in autumn, was even lower at $\$ 36.23 \mathrm{Mg}^{-1}$.

\section{Discussion}

The purpose of the partial LCA was not to estimate a complete $\mathrm{CO}_{2}$ eq. footprint for cow-calf production (indeed footprint of labor, vaccine, and feed additives other than corn are not tracked), but rather to quantify relative differences across production practices that principally hinge on supplemental corn and forage yield. As such, we found positive outcomes for using SG in lieu of $B G+T F+C$, similarly to other reports [4-7]. The documented high nutrient-use efficiency of switchgrass $[8,24]$ compared with conventional forages, along with the use of locally produced and inexpensive organic fertilizer resulted in positive net GHG emissions- and profitability changes. Therefore, the results may well hinge on the availability of poultry litter at low cost to make the type of targeted farm operation a favorable candidate for adoption of dual-use SG. Given a local marketing outlet for SG bio-feedstock, which remains hypothetical at this time, mixed operations with available poultry litter in close proximity to pasture and hay land can capitalize on greater yield and access to another potential market (biomass for biorefineries) to offset added costs (fertilizer, twine, and corn) as a function of lower feed-quality hay.

Another advantage is the timing of hay harvest. Harvesting of SG at a growth stage before the nutritive value deteriorates occurs later in the spring (late May to mid-June in Arkansas) than for TF (May) and, as such, potentially offers a way to mitigate weather risk, as rainfall events tend to be more common at the time of the TF harvest than in June when SG harvest would occur [28]. Nonetheless, the timing of SG hay harvest to achieve appropriate hay quality and palatability for cattle is critical and not without risk. Ashworth et al. [29], for example, documented effects of cutting height on stand survival. Importantly, producers should not attempt to maximize hay yield by choosing too low a cutting height as regrowth for biomass harvest and stand longevity could be compromised. A shorter SG stand life leads to much greater stand maintenance and establishment charges [27].

Nonetheless, lessening the net GHG footprint per farm, and per unit mass of live weight of cattle produced, while enhancing profitability and supplying biomass without changing land required with constant cattle output, makes SG hay look promising. Switchgrass that is stored on a farm would offer biorefineries access to relatively low-cost feedstock at a time when biomass from other sources may be less available (winter and spring). We also note that SG establishment and changes in forage species mix on land dedicated to hay production is not without risk or potential supply disruption. Hence, the breakeven prices for SG noted above are likely too small as operators need compensation for making changes to their operations as well as attendant risk consequences. While not directly modeled, we think that the equipment and operator time requirement changes could be small with the change to SG as the number of harvests of hay remains the same. Despite greater bale handling needs with SG, higher yield should enhance the production efficiency and hence the added fuel use was minor. Further, the cost of production and resultant physical output are expected to vary across operations as cow-calf production and hay management practices, weather patterns, soil type, and conventional forage species composition differ by producer and local growing conditions. Finally, while the cattle output and land size were held constant, the operation did require more purchases of fertilizer, corn, and twine.

Overall, the introduction of SG as a forage species alternative to BG $+\mathrm{TF}+\mathrm{C}$ appears promising. Should a producer be able to monetize added soil carbon sequestration and/or 
reduced emissions in a carbon market, the potential for adoption of SG as a hay alternative would increase. Finally, a greater SG price may prompt a producer to increase fertilizer use. This could enhance the farm profitability further and thereby the supply potential of SG from $122 \mathrm{Mg}$ (dry matter per farm) to a greater amount. By multiplying $122 \mathrm{Mg}$ per farm by the approx. 200,000 similar farms in the Southeastern U.S., the supply potential for the region exceeds $23 \mathrm{MM} \mathrm{Mg}$. Assuming a biofuel conversion rate of $189 \mathrm{~L} \mathrm{Mg}^{-1}$ for SG, the annual biofuel production from this source would reach nearly $4.5 \times 10^{9} \mathrm{~L}$ for the region. As noted above, however, such supply estimates are subject to considerable error given heterogeneous operating conditions under which farms operate. Nonetheless, the analysis offers insight about the biomass potential sourced from these types of farms.

Author Contributions: Conceptualization, M.P.P., A.J.A., and C.P.W.; Methodology, M.P.P.; software, formal analysis and investigation, M.P.P.; resources, M.P.P.; data curation, M.P.P., A.J.A. and C.P.W.; writing—original draft preparation, M.P.P.; writing—review and editing, M.P.P., A.J.A. and C.P.W.; visualization, M.P.P. All authors have read and agreed to the published version of the manuscript.

Funding: This research received no external funding.

Institutional Review Board Statement: Not applicable.

Informed Consent Statement: Not applicable.

Data Availability Statement: FORCAP modifications from the available website version are available upon request. Please e-mail M. Popp.

Acknowledgments: This work was supported by the U.S. Department of Agriculture, National Institute of Food and Agriculture Hatch under project 02698.

Conflicts of Interest: The authors declare no conflict of interest.

\section{References}

1. Halder, P.; Azad, K.; Shah, K.; Sarker, E. Prospects and technological advancement of cellulosic bioethanol ecofuel production. In Advances in Eco-Fuels for a Sustainable Environment; Azad, K., Ed.; Woodhead Publishing: Cambridge, UK, 2019 ; pp. $211-236$. [CrossRef]

2. Mat Aron, N.S.; Khoo, K.S.; Chew, K.W.; Show, P.L.; Chen, W.; Nguyen, T.H.P. Sustainability of the four generations of biofuels-A review. Int. J. Energy Res. 2020, 44, 9266-9282. [CrossRef]

3. U.S. Department of Agriculture, National Agricultural Statistics Services (USDA-NASS). 2017 Census of Agriculture Volume 1, Chapter 1, Table 75. Summary by North American Industry Classification. 2020. Available online: https://www.nass.usda.gov / Publications/AgCensus/2017/Full_Report/Volume_1,_Chapter_1_State_Level/ (accessed on 27 October 2020).

4. Boyer, C.; Zechiel, K.; Keyser, P.; Rhinehart, J.; Bates, G. Risk and Returns from Grazing Beef Cattle on Warm-Season Grasses in Tennessee. Agron. J. 2020, 112, 301-308. [CrossRef]

5. Mosali, J.; Biermacher, J.; Cook, B.; Blanton, J., Jr. Bioenergy for Cattle and Cars: A Switchgrass Production System that Engages Cattle Producers. Agron. J. 2013, 105, 960-966. [CrossRef]

6. Richner, J.; Kallenbach, R.; Roberts, C. Dual Use Switchgrass: Managing Switchgrass for Biomass Production and Summer Forage. Agron. J. 2014, 106, 1438-1444. [CrossRef]

7. McIntosh, D.; Bates, G.; Allen, F.; Harper, C.; Waller, J.; Birckhead, J.; Backus, W. The Impact of Harvest Timing on Biomass Yield from Native Warm-Season Grass Mixtures. Agron. J. 2015, 107, 2321-2326. [CrossRef]

8. Popp, M.; Ashworth, A.; Moore, P., Jr.; Owens, P.; Douglas, J.; Pote, D.; Jacobs, A.; Lindsay, K.; Dixon, B. Fertilizer Recommendations for Switchgrass: Quantifying Economic Effects on Quality and Yield. Agron. J. 2018, 110, 1854-1861. [CrossRef]

9. Popp, M.; Smith, S.A.; Keeton, D.; Maples, W. Forage \& Cattle Planner (FORCAP v 2). Department of Agricultural Economics and Agribusiness, University of Arkansas. Available online: http:/ / agribusiness.uark.edu/decision-support-software.php (accessed on 23 March 2021).

10. Tester, C.; Popp, M.; Kemper, N.; Nalley, L.; West, G. Impact of Weather and Herd Size Management on Beef Cow Profitability. J. Agric. Appl. Econ. 2019, 51, 545-567. [CrossRef]

11. Smith, S.A.; Popp, M.; Keeton, D.; West, C.; Coffey, K.; Nalley, L.; Brye, K. Economic and Greenhouse Gas Emission Response to Pasture Species Composition, Stocking Rate, and Weaning Age by Calving Season, Farm Size, and Pasture Fertility. Agric. Resour. Econ. Rev. 2016, 45, 98-123. [CrossRef]

12. Intergovernmental Panel on Climate Change (IPCC). 2006 IPCC Guidelines for National Greenhouse Gas Inventories; Emissions form Livestock and Manure Management; Cambridge University Press: Cambridge, UK, 2018; Volume 4, Chapter 10; Available online: https://www.ipcc-nggip.iges.or.jp/public/2006gl/pdf/4_Volume4/V4_10_Ch10_Livestock.pdf (accessed on 17 April 2021). 
13. Long Trail Sustainability. DataSmart 2016 Life Cycle Inventory. 2016. Available online: https:/ / earthshiftsustainability.com/ services/software/datasmart-life-cycle-inventory/ (accessed on 23 March 2021).

14. United States Environmental Protection Agency (USEPA). Inventory of U.S. Greenhouse Gas Emissions and Sinks: 1990-2015; EPA 430-P-17-001; USEPA: Washington, DC, USA, 2017. Available online: https:/ / www.epa.gov/ghgemissions/inventory-usgreenhouse-gas-emissions-and-sinks-1990-2015 (accessed on 23 March 2021).

15. Lal, R. Carbon emission from farm operations. Environ. Int. 2004, 30, 981-990. [CrossRef] [PubMed]

16. Thoma, G.; Popp, J.; Nutter, D.; Shonnard, D.; Ulrich, R.; Matlock, M.; Kim, D.S.; Niederman, Z.; Kemper, N.; East, C.; et al. Greenhouse Gas Emissions from Milk Production and Consumption in the United States: A Cradle-to-Grave Life Cycle Assessment Circa 2008. Int. Dairy J. 2013, 31, S3-S14. [CrossRef]

17. Rotz, C.; Asem-Hiablie, S.; Dillon, J.; Bonifacio, H. Cradle-to-Farm Gate Environmental Footprints of Beef Cattle Production in Kansas, Oklahoma, and Texas. J. Anim. Sci. 2015, 93, 2509-2519. [CrossRef] [PubMed]

18. Mississippi State University. Delta Planning Budgets. Mississippi State: Department of Agricultural Economics, Mississippi State University, 2016-2020. Available online: https:/ / www.agecon.msstate.edu/whatwedo/budgets/archive.php (accessed on 22 February 2021).

19. U.S. Department of Agriculture, National Agricultural Statistics Services (USDA-NASS). Quick Stats [Database]; USDA-NASS: Washington, DC, USA, 2021. Available online: https:/ / quickstats.nass.usda.gov/ (accessed on 15 January 2021).

20. Kirchgessner, M.; Windisch, W.; Müller, H.L.; Kreuzer, M. Release of Methane and of Carbon Dioxide by Dairy Cattle. United States Department of Energy, Office of Science and Technical Information. Agribiol. Res. 1991, 91-102. Available online: https: / / www.osti.gov / etdeweb / biblio/6065141 (accessed on 23 March 2021).

21. Popp, M.; Nalley, L.; Fortin, C.; Smith, S.A.; Brye, K. Estimating Net Carbon Emissions and Agricultural Response to Carbon Offset Policies. Agron. J. 2011, 103, 1132-1143. [CrossRef]

22. Caldwell, J.; Coffey, K.; Jennings, J.; Philipp, D.; Young, A.; Tucker, J.; Hubbell, D.; Hess, T.; Looper, M.; West, C.; et al. Performance by Spring and Fall-Calving Cows Grazing with Full, Limited, or No Access to Toxic Neotyphodium coenophialum-Infected Tall Fescue. J. Anim. Sci. 2013, 91, 465-476. [CrossRef] [PubMed]

23. Smith, S.A.; Caldwell, J.D.; Popp, M.; Coffey, K.P.; Jennings, J.A.; Savin, M.C.; Rosenkrans, C.F., Jr. Tall Fescue Toxicosis Mitigation Strategies: Comparisons of Cow-Calf Returns in Spring- and Fall-Calving Herds. J. Agric. Appl. Econ. 2012, 44, 577-592. [CrossRef]

24. Cahill, N.; Popp, M.; West, C.; Rocateli, A.; Ashworth, A.; Farris, R., Sr.; Dixon, B. Switchgrass Harvest Time Effects on Nutrient Use and Yield: An Economic Analysis. J. Agric. Appl. Econ. 2014, 46, 487-507. [CrossRef]

25. U.S. Department of Agriculture, Agricultural Marketing Service. Feeder and Slaughter Cattle Summary Reports; USDA-AMS: Little Rock, AR, USA, 2021. Available online: https:/ / www.ams.usda.gov/market-news/livestock-poultry-grain\#Cattle (accessed on 15 February 2021).

26. Popp, M.; Nalley, L.L. Modeling Interactions of a Carbon Offset Policy and Biomass Markets on Crop Allocations. J. Agric. Appl. Econ. 2011, 43, 399-411. Available online: https:/ / search.proquest.com/scholarly-journals/modeling-interactions-carbon-offsetpolicy / docview / 889336731/ se-2?accountid=8361 (accessed on 27 March 2021). [CrossRef]

27. Lindsay, K.; Cahill, N.; Popp, M.; Smith, S.A.; West, C.; Ashworth, A.; Rocateli, A.; Farris, R., Jr.; Kakani, G.; Fritschi, F.; et al. Energy Crop Analysis \& Planning (ENCAP) User Manual 2015. Department of Agricultural Economics and Agribusiness, University of Arkansas. Available online: http:/ / agribusiness.uark.edu/decision-support-software.php (accessed on 23 March 2021).

28. Popp, M.; Searcy, S.; Sokhansanj, S.; Smartt, J.; Cahill, N. Influence of Weather on the Predicted Moisture Content of Field Chopped Energy Sorghum and Switchgrass. Appl. Eng. Agric. 2015, 31, 179-190. [CrossRef]

29. Ashworth, A.; Keyser, P.; Holcomb, E.; Harper, C. Yield and Stand Persistence of Switchgrass as Affected by Cutting Height and Variety. Forage Grazinglands. 2013, 11, 1-7. [CrossRef] 